\title{
An unusual suctorial montacutid bivalve from the deep Atlantic
}

\author{
J.A. Allen \\ *University Marine Biological Station, Millport, Isle of Cumbrae, Scotland, KA28 0EG and Woods Hole \\ Oceanographic Institution, MA 02543, USA. *Address for correspondence
}

\begin{abstract}
The shell and internal anatomy of the montacutid bivalve Mysella verrilli is described for the first time. The species is remarkable in that the oesophagus has developed into a suctorial proboscis. This has been accompanied by the loss of the palps. In addition the gonads have been extended from the dorsal part of the body to form two gill-like extensions to which the reduced inner demibranchs attach along the postero-ventral margin. Mysella verrilli broods its young in the mantle cavity to the late veliger stage before releasing them. It is believed that the species is probably a suctorial ectoparasite on a soft-bodied benthic invertebrate.
\end{abstract}

\section{INTRODUCTION}

The Montacutidae is one of a number of families included in the heterodont bivalve superfamily Galeommatoidea. Members of the superfamily, although showing plesiomorphic features, usually lead highly specialized lifestyles in association with another animal. The Montacutidae and the genus Mysella in particular, live in association with other invertebrates (e.g. Boss, 1965; Ockelmann \& Muus, 1978; Morton \& Scott, 1989) and tend to have specialized reproductive strategies including the brooding of their young (Deroux, 1960, 1961; Chanley \& Chanley, 1970; Ockelmann \& Muus, 1978; O’Foighil, 1985).

The present paper describes for the first time the unusual and unique morphology of Mysella tumidula verrilli (Dall, 1899). This species was first taken from the deep Atlantic by the Steamer 'Albatross' of the United States Fish Commission and lately in epibenthic sled samples by ships of the Woods Hole Oceanographic Institution (WHOI). The subspecies is now raised to species level.

\section{DESCRIPTION}

Superfamily GALEOMMATOIDEA Gray, 1840 Family MONTACUTIDAE Clark, 1855

Genus Mysella Angas, 1877

Type species: (original designation) Mysella anomala Angas, 1877. See Morton \& Scott (1989) for a diagnosis of the genus.

$$
\text { Mysella verrilli (Dall, 1899) }
$$

Type locality: US Fish Commission steamer 'Albatross' Station 2103, off Delaware Bay, $38^{\circ} 47.20^{\prime} \mathrm{N} 72^{\circ} 37.00^{\prime} \mathrm{W}$, $1986 \mathrm{~m}$.

Type specimen: holotype, USNM no. 35412.

Cited specimens: BMNH no. 19991557.

Montacuta tumidula Verrill, 1884: 225 \& 279.

Montacuta tumidula Verrill, 1885: 575.

Montacuta tumidula Verrill \& Bush, 1898: 781, plate xciii, figure 6; plate xci, figures $1 \& 2$.
Mysella (tumidula var.) verrilli Dall, 1899: 890.

Mysella tumidula verrilli Abbott, 1974: 474.

\section{WHOI material examined}

Cruise, station, no., longitude, latitude, depth (m), date, gear.

North America Basin

Atlantis II 24, 115, 24, 39 $39.2^{\prime} \mathrm{N} 70^{\circ} 24.5^{\prime} \mathrm{W}, 2030,15$ August 1966, ES (epibenthic sledge); 128, 2, 39 $46.5^{\prime} \mathrm{N}$ $70^{\circ} 45.2^{\prime} \mathrm{W}, 1254,16$ December 1966, ES; 30, 131, $3+\mathrm{v}^{\prime} 39^{\circ} 38.5^{\prime} \mathrm{N} 70^{\circ} 36.5^{\prime} \mathrm{W}, 2178$, 18 December 1966, ES.

\section{West European Basin}

Chain 106, 309, $4+1 \mathrm{~s}^{\prime} 52^{\circ} 21.1^{\prime} \mathrm{N} 12^{\circ} 07.4^{\prime} \mathrm{W}, 485,16$ August 1972, ES; 313, $1,51^{\circ} 32.2^{\prime} \mathrm{N} 12^{\circ} 35.9^{\prime} \mathrm{W}, 1500,17$ August 1972, ES.

West Mediterranean Basin

Atlantis II 59, 234, 1, 32 $29.0^{\prime} \mathrm{N} 16^{\circ} 53.0^{\prime} \mathrm{W}, 1446,11$ September 1970, ES.

Angola Basin

Atlantis II $42,188,30,23^{\circ} 00.0^{\prime} \mathrm{S} 12^{\circ} 58.0^{\prime} \mathrm{E}, 622,16$ May 1968, ES.

Argentine Basin

Atlantis II 60, 239, 76, 36 $49.0^{\prime} \mathrm{S} \quad 53^{\circ} 15.4^{\prime} \mathrm{W}, 1679,11$ March 1970, ES.

\section{Also examined}

The type specimen USNM no. 35412 and other specimens all part of the suite Verrill $(1884,1885)$ and Verrill \& Bush (1898) originally examined, namely YPM no. 24003, one valve, USFG Steamer 'Albatross', Station 2709 (original no. 78375), $40^{\circ} 07^{\prime} \mathrm{N} 67^{\circ} 54^{\prime} \mathrm{W}, 1576 \mathrm{~m}$ and YPM no. 24004, two mounted valves, USFG Steamer 'Albatross', Station 2115 (original no. 38190), 35 $49^{\prime} 30^{\prime \prime} \mathrm{W}$ $74^{\circ} 34^{\prime} 45^{\prime \prime} \mathrm{W}, 1534 \mathrm{~m}$.

\section{Distribution}

Widely distributed within the Atlantic at mid slope to lower slope depths, 485-2178 m. 
Mysella tumidula s.s. was first recorded by Jeffreys (1866) (as Montacuta tumidula) from relatively shallow-water $(33-146 \mathrm{~m})$ in the Hebrides and later further described and figured by him (Jeffreys, 1867, 1869) and by Marshall (1897) (Figure 1). Verrill (1884, 1885) and Verrill \& Bush (1898) recorded what they believed to specimens of this species which were taken from deep-water (1534-1985 m) off the east coast of the USA (Figure 2). Dall (1899) reexamined the specimens identified by Verrill and compared them with the type and other specimens of M. tumidula (present reference numbers: USNM 170421, 170423 and 170424) and concluded that they were not the same species. Dall (1899) regarded the specimens collected off the east coast of America as a variety of $M$. tumidula. The same comparative process has been applied to the specimens collected by the WHOI research ships (see above). The differences were confirmed by the author and by Dr J.D. Taylor who kindly made camera lucida drawings (Figure 1) of a specimen of $M$. tumidula (BMNH no. 1889.2.25.104-5) and one of the present specimens of $M$. verrilli (BMNH cited specimens no. 19991557). Mysella verrilli has never been adequately described.

\section{Shell description (Figures 3-7).}

Shell small (length of specimens examined range from 1.5 to $3.7 \mathrm{~mm}$ ), ovate, moderately wide. Ratios of major shell dimensions: height:length $=0.72$, width:length $=0.53$. Relatively broadly spaced concentric growth rings with many fine concentric striae between, growth bands alternate in colour from dark to pale cream (Figure 3); umbo far posterior, small, inturned and slightly posterior; postero-dorsal shell margin steeply inclined ventrally, more or less straight, meets posterior limit of shell ventral to mid-horizontal axis, posterior margin slightly flattened, postero-ventral, ventral, antero-ventral and anterior margins smoothly curved, from umbo posterodorsal margin straight and inclined slightly dorsally as far as mid-line, then slightly ventrally to meet anterior margin in smooth curve (Figure 3); a faint, narrow, escutcheon present (Figure 3); no lunule; hinge-plates narrow (Figure 5), left posterior hinge plate more narrow than anterior being little more than thickened shell

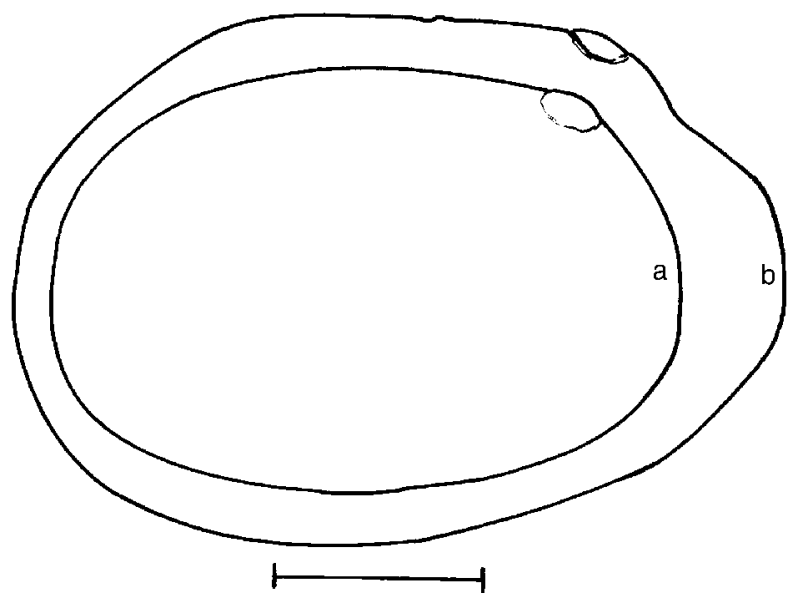

Figure 1. Camera lucida outline drawings of shells from the left side by Dr J. Taylor (BMNH) of: (A) Mysella verrilli from Atlantis II, station 118; and (B) Mysella tumidula from the Hebrides, BMNH no. 1889.2.25.104-5. Scale bar: $1.0 \mathrm{~mm}$.

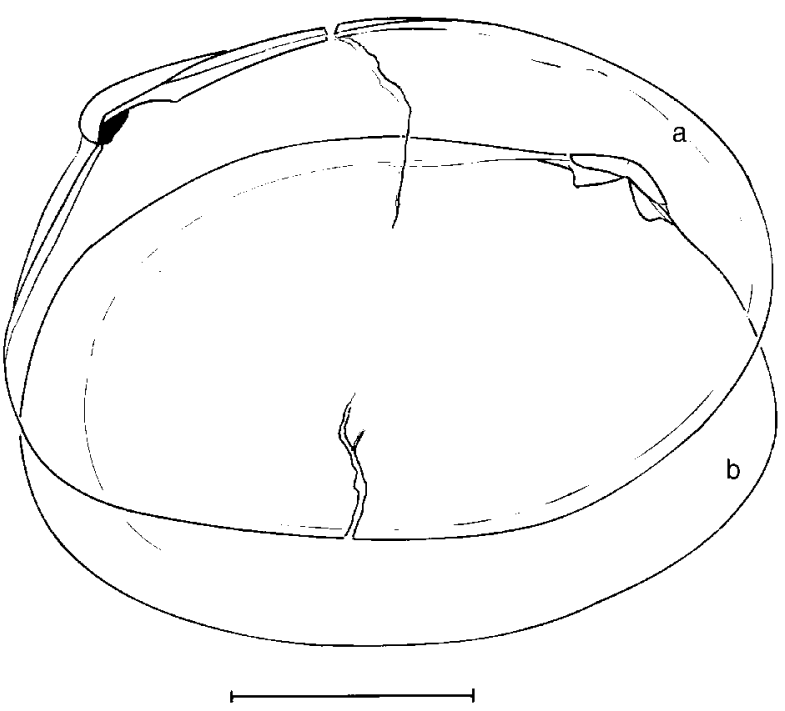

Figure 2. Outline drawings of the internal features of two valves from the original material examined by Verrill: (A) left valve (mounted on card) from Albatross station 2115, YPM no. 24004, black area below umbo is the remains of the dried ligament; (B) right valve from Albatross station 2709, YPM no. 24003. Scale bar: $1.0 \mathrm{~mm}$.
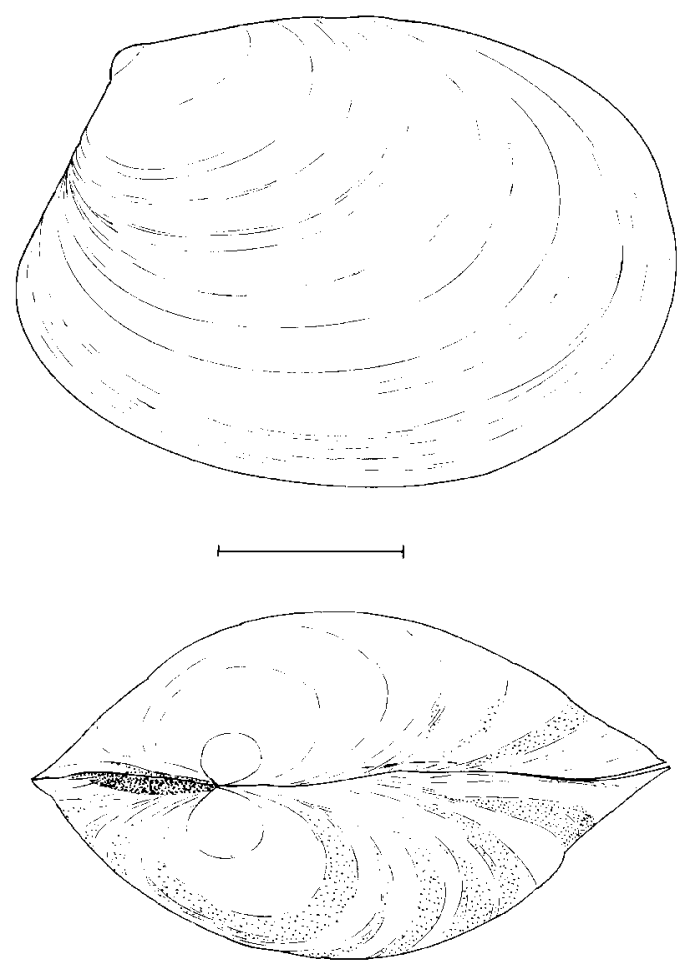

Figure 3. Right lateral and dorsal views of a shell from Atlantis II, station 115, North America Basin. Scale bar: $1.0 \mathrm{~mm}$.

margin, left anterior hinge plate slightly more thickened with longitudinal groove parallel to margin and extending to mid-line, left hinge has no teeth, right hinge plate also narrow but bearing two similar teeth at ventral margin of plate ventral to umbo (Figure 6), teeth extend obliquely as slightly elongate flanges that hook underneath left hinge, right posterior hinge plate with groove parallel to margin, right anterior hinge plate without groove; internal ligament dumb-bell-shaped with ventral 


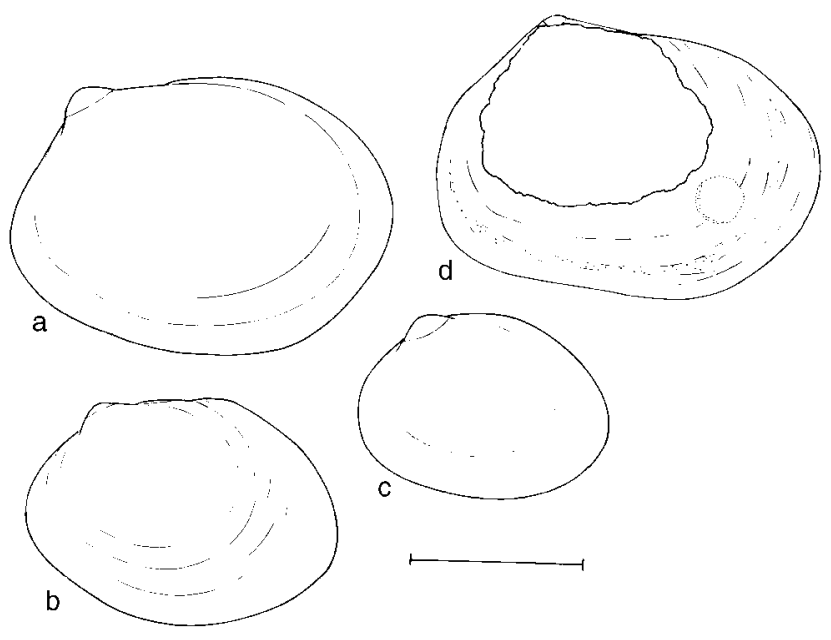

Figure 4. Right lateral views of specimens $(A-C)$ from Atlantis II, station 115, North America Basin; and (D) from Atlantis II, station 234, West Mediterranean Basin to show inter- and intrapopulation differences in shell outline and shell erosion and evidence of attack by a boring gastropod. Scale bar: $1.0 \mathrm{~mm}$.

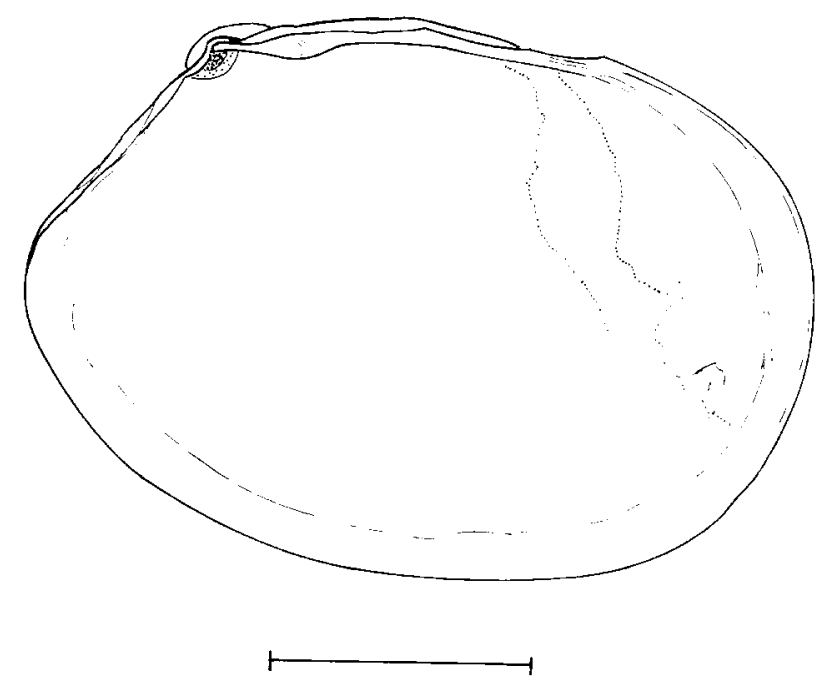

Figure 5. Internal view of left valve of a specimen from Atlantis II, station 115, North America Basin. Scale bar: $1.0 \mathrm{~mm}$.

somewhat asymmetrical lithodesma (Figure 7), ligament lies ventral to hinge and extends externally, anteriorly and posteriorly, by fused periostracum. Prodissoconch relatively large $307-345 \mu \mathrm{m} \quad($ mean $=332.5 \mu \mathrm{m}, \quad \mathrm{N}=11)$ (Figure 6).

Mysella verrilli differs from $M$. tumidula in that it is truncated posteriorly and the umbo is more posterior then M. tumidula. Unlike $M$. verrilli, the postero-dorsal shell margin in $M$. tumidula is somewhat concave while the posterior margin is extended (Figure 1). Some inter- and intrabasinal differences in the shape of the shell outline of M. verrilli were seen (Figures $3 \& 4$ ). In particular, one shell from the western Mediterranean (Figure 4D), was more truncate posteriorly and with a straighter ventral shell margin. The prodissoconch has a broad margin reminiscent of that of Neolepton (Salas \& Gofas, 1998) (Figure 6). The variation in size of the prodissoconch is perhaps indicative of the varying length of time taken

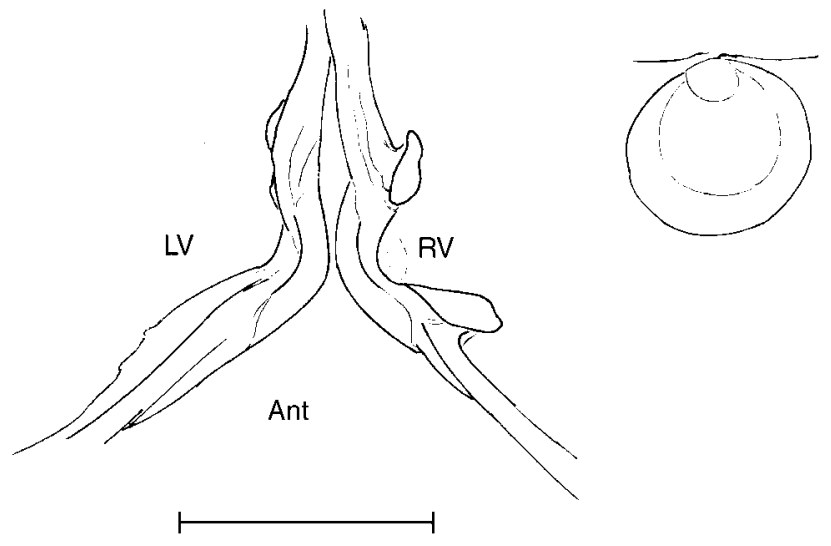

Figure 6. Lateral views of the left and right hinge plates and the left prodissoconch of a specimen from the type locality, Atlantis II, station 115, North America Basin. Scale bar: $0.5 \mathrm{~mm}$.

before the veliger encounters and settles on the host species.

The dumb-bell-shaped internal ligament is slung ventral to the umbo and hinge passing between the anterior and posterior modified lateral teeth of the right valve (Figure 7). Externally it is extended by fused periostracum, the anterior section being shorter than the posterior (Figure 7A). The internal ligament comprises inner and outer layers with a lithodesma lying ventral and central to the neck of the dumb-bell (Figure 7B,C).

This is the third montacutid species in which a lithodesma has been reported. The lithodesma was first reported in two species of Montacutona, a very closely related, if not synonymous, genus to Mysella, by Morton (1980) and it may be that the lithodesma has been overlooked in other montacutids. As Morton (1980) points out, until his report the lithodesma was only known in species of the subclass Anomalodesmata. Its presence in the Montacutidae does not necessarily imply a close relationship but is possibly related to the structural characteristics of this type of internal ligament in association with a relatively weak hinge.

\section{Internal morphology (Figures 8-16).}

The mantle margin, as is typical in galeommatoideans, is broad. Much of this breadth is taken up by the inner muscular mantle fold, with the middle sensory and outer folds not greatly enlarged (Figure 13). The sensory fold bears a scattering of small sensory papillae. Internal to the inner fold and within the epithelium is a band of radial pallial muscles (Figure 8). These latter are in regularly spaced groups of fibres. The fibres of each group radiate through a small angle. The periostracum extends to some extent beyond the shell margin and is relatively stout. It is firmly attached to the periostracal groove between outer and sensory mantle folds and it is likely that as in other montacutids, the mantle margin can be extended over the outside of the shell to some degree. In addition to the radial muscles there are subepithelial gland cells internal to the inner mantle fold (Figure 13). These are particularly prevalent anteriorly and ventral to the anterior adductor where it is construed that the inhalant current enters the mantle cavity. Posteriorly there is a 

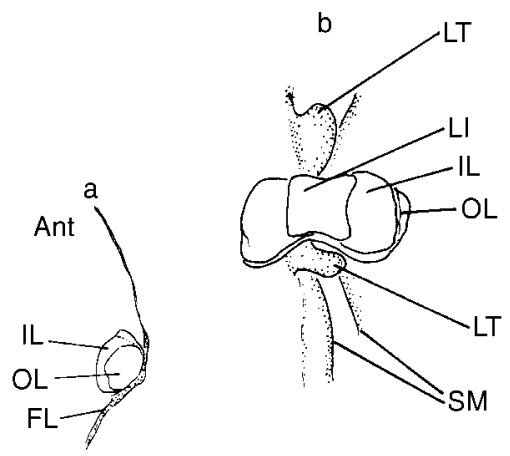

Figure 7. (A) Lateral; (B) ventral; (C) posterior views of the ligament of a specimen from Atlantis II, station 115, North America Basin. Scale bars: A-C, $1.0 \mathrm{~mm}$; D, $0.5 \mathrm{~mm}$. FL, fused periostracum; IL, inner layer of ligament; AS, surface of attachment; FL, fused periostracum; IL, inner layer of ligament; OL, outer layer of ligament; LI, lithodesma; LT, lateral tooth; SM, shell margin.

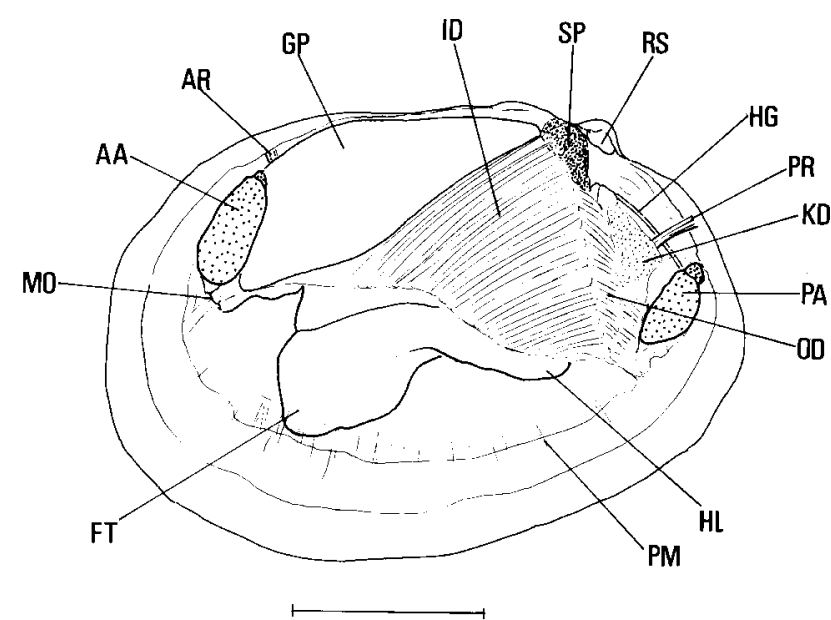

Figure 8. Left lateral view of the internal morphology of a specimen from Atlantis II, station 115, North America Basin. Scale bar: $1.0 \mathrm{~mm}$. AA, anterior adductor muscle; AR, anterior pedal retractor muscle; FT, foot; GP, gonadial pouch; HG, hindgut; HL, heel of foot; ID, inner demibranch; $\mathrm{KD}$, kidney; MO, mouth; OD, outer demibranch; PA, posterior adductor muscle; PM, pallial muscles; PR, posterior pedal retractor muscle; RS, resilium (internal ligament); SP, sperm.

single exhalant aperture that is separated from the pedal gape by fusion of the opposing inner folds (Figure 10). Mantle glands are also present internal to the inner mantle fold at the posterior limit of the pedal aperture.

The anterior and posterior adductor muscles are large and oval in cross section, the anterior muscle being more elongate than the posterior (Figures 8 \& 9). The large size of these probably correlates with the slender hinge, with its weak dentition and small, transverse ligament. These muscle types are typical of epifaunal bivalves that actively open and close their shell valves.

The foot is relatively large, broad and highly muscular. The anterior and posterior pedal retractor muscles are particularly stout (Figure 9). There is a mid-ventral groove along the posterior part of the sole and although no byssal thread was seen in any adult specimen there is a large basiphyllic gland dorsal and internal to the foot musculature that extends ventrally in the heel to open by

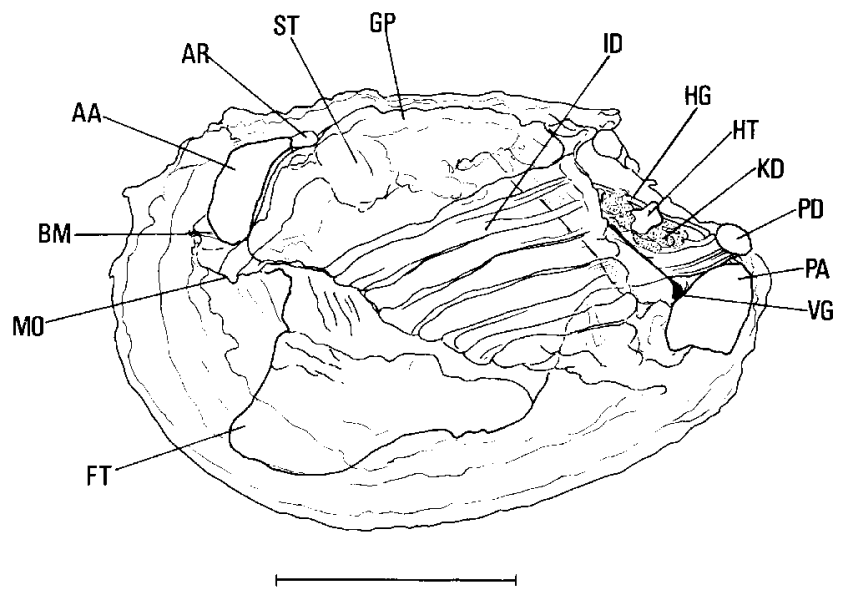

Figure 9. Left lateral view of the internal morphology of a juvenile specimen from Atlantis II, station 115, North America Basin. Scale bar: $0.5 \mathrm{~mm}$. AA, anterior adductor muscle; AR, anterior pedal retractor muscle; BM, buccal protractor muscles; FT, foot; GP, gonadial pouch; HG, hindgut; HT, heart; ID, inner demibranch; KD, kidney; MO, mouth; PA, posterior adductor muscle; PD, pedal retractor attachment; ST, stomach; VG, visceral ganglion.

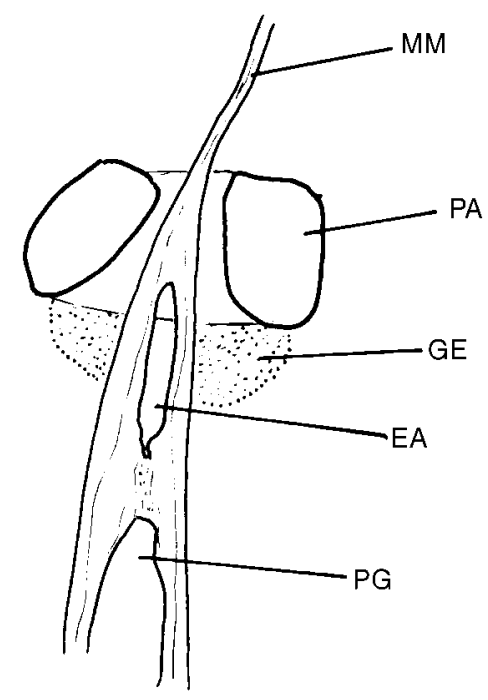

Figure 10. Detail of the posterior mantle margin as seen in posterior view of a specimen from Atlantis II, station 115, North America Basin. Scale bar: $0.5 \mathrm{~mm}$. EA, exhalent aperture; GE, mantle glands; MM, mantle margin; PA, posterior adductor muscle; $\mathrm{PG}$, pedal gape.

a short duct at the posterior end of the mid-ventral groove. In one specimen a sand grain was found attached to the duct opening (Figure 11). In addition to this major pedal gland, a number of eosinophilic glands cells are scattered laterally within the pedal musculature that open onto the lateral surfaces of the foot. It is assumed that the foot is very active and that the animal crawls upright, being lubricated by the mucus from these glands, in much the same way as in gastropod locomotion. This type of locomotion has been observed in galeommatoideans in general (Popham, 1940) and other species of Mysella in 


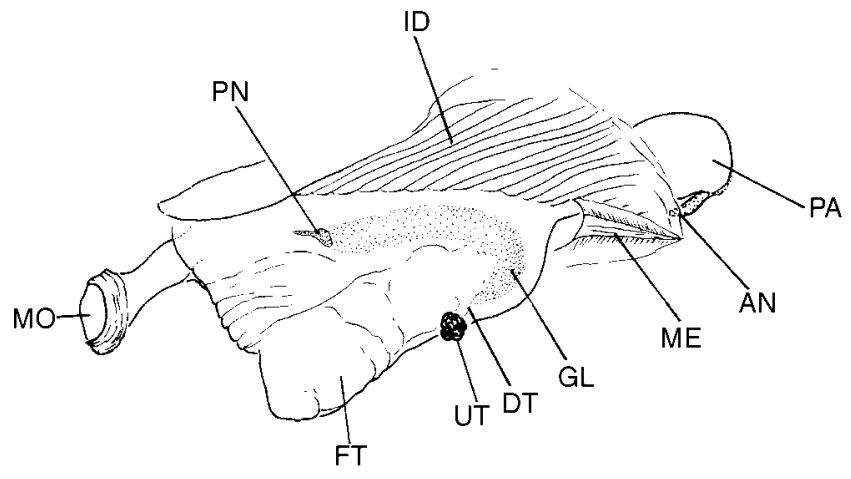

Figure 11. Detail of the foot as seen from the left side of a specimen from Atlantis II, station 115, North America Basin. Scale bar: $0.5 \mathrm{~mm}$. AN, anus; DT, duct; FT, foot; GL, pedal gland; ID, inner demibranch; ME, gill fusion; $\mathrm{MO}$, mouth; PA, posterior adductor muscle; PN, pedal ganglion; UT, sand grain.

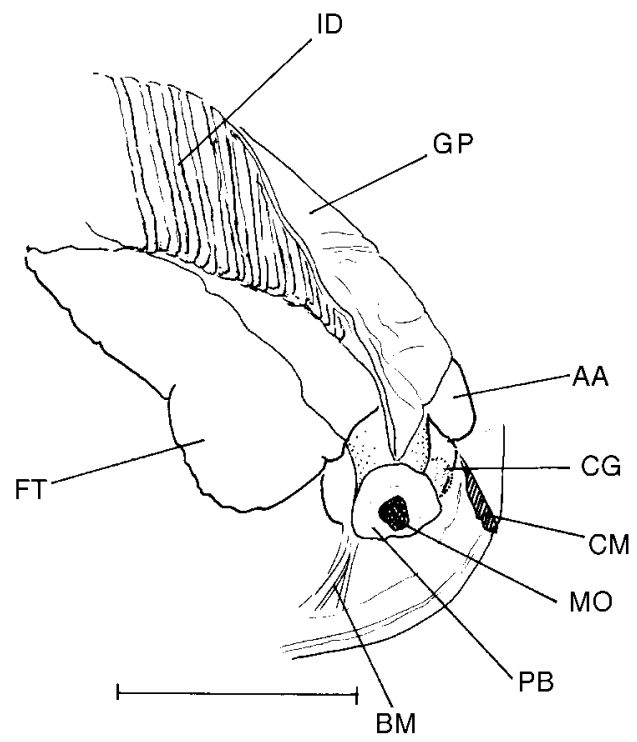

Figure 12. Detail of the region of the mouth from the right side of a specimen from Atlantis II, station 115, North America Basin. Scale bar: $0.5 \mathrm{~mm}$. AA, anterior adductor muscle; BM, buccal protractor muscles; $\mathrm{CG}$, cerebral ganglion; CM, cut mantle margin; FT, foot; GP, gonad; ID, inner demibranch; MO, mouth; $\mathrm{PB}$, proboscis.

particular [e.g. M. bidentata (personal observation) and M. cuneata (Gage, 1968)]. There is a well-developed paired pedal ganglion at the junction of the foot musculature and the viscera at the anterior limit of the basiphilic pedal gland (Figure 11). Anterior and close to the ganglion is a pair of spherical statocysts.

The morphology of the gills and viscera is remarkable. The gills comprise inner and outer demibranchs with the inner demibranchs being much the larger (Figure 8). They are homorhabic. The inner demibranchs extend over the posterior half of the visceral mass. Anteriorly the descending lamellae are attached to the oblique posterior margin of a flattened leaf-like gonadial visceral extension via a fine tissue membrane (equivalent in part to the gill axis and in part to the attachment of the anterior edge to the body wall in other bivalves) (see below). The

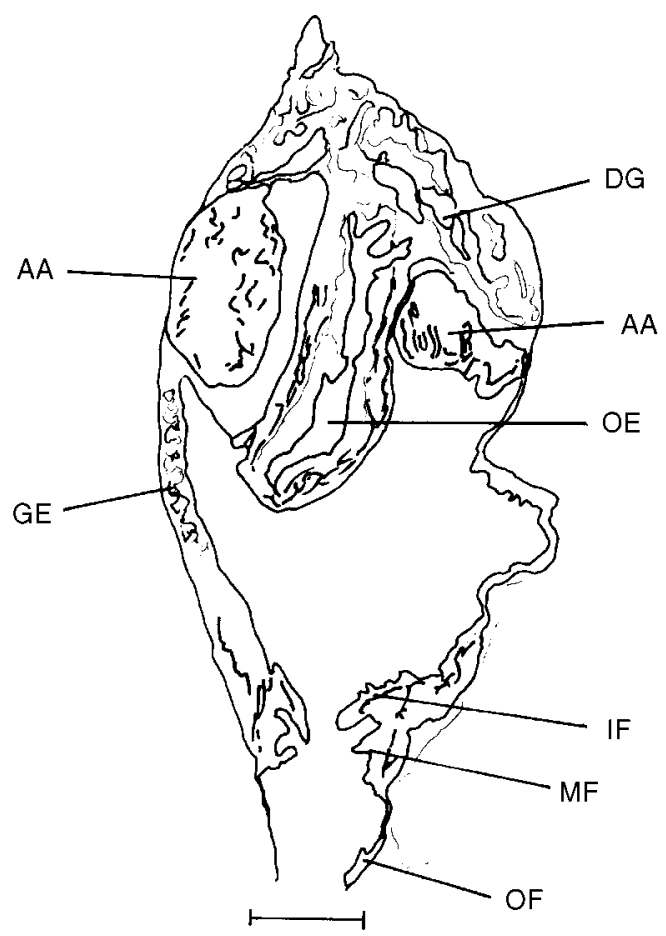

Figure 13. Transverse section through the buccal region of a specimen from Atlantis II, station 115, North America Basin. Scale bar: $0.1 \mathrm{~mm}$. AA, anterior adductor muscle; DG, digestive gland; GE, mantle glands; IF, inner muscular mantle fold; MF, middle sensory mantle fold; OE, oesophagus; $\mathrm{OF}$, outer mantle fold.

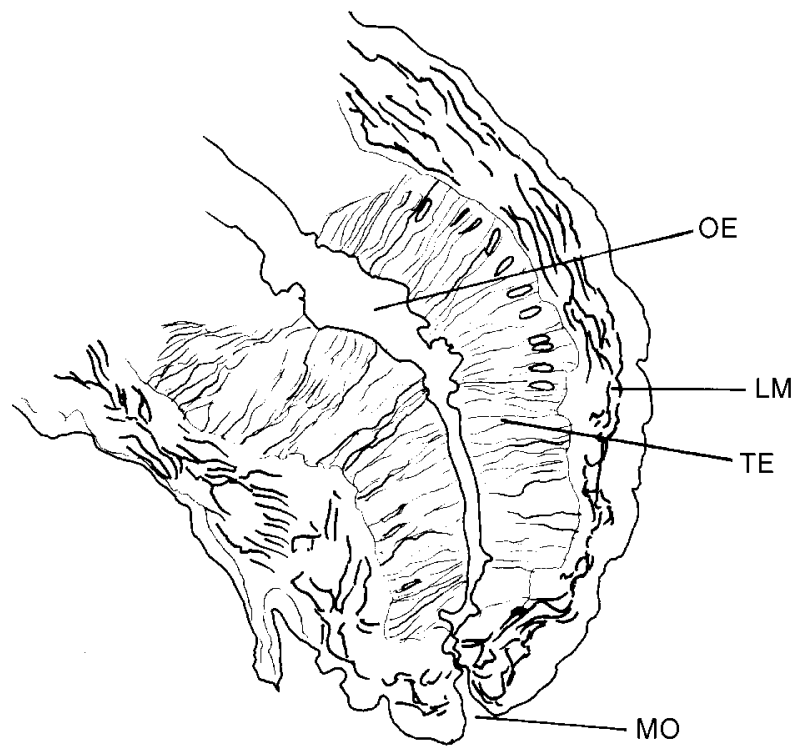

Figure 14. Transverse section through the buccal proboscis of a specimen from Atlantis II, station 115, North America Basin. Scale bar: $0.1 \mathrm{~mm}$. LM, longitudinal muscles; MO, mouth; OE, oesophagus; TE, thickened oesophageal columnar epithelium.

membrane extends from immediately anterior to the umbo to the antero-ventral margin of the visceral part of the body close to the mouth (Figure 12). The ascending lamellae of inner demibranchs attach dorsally by a tissue 


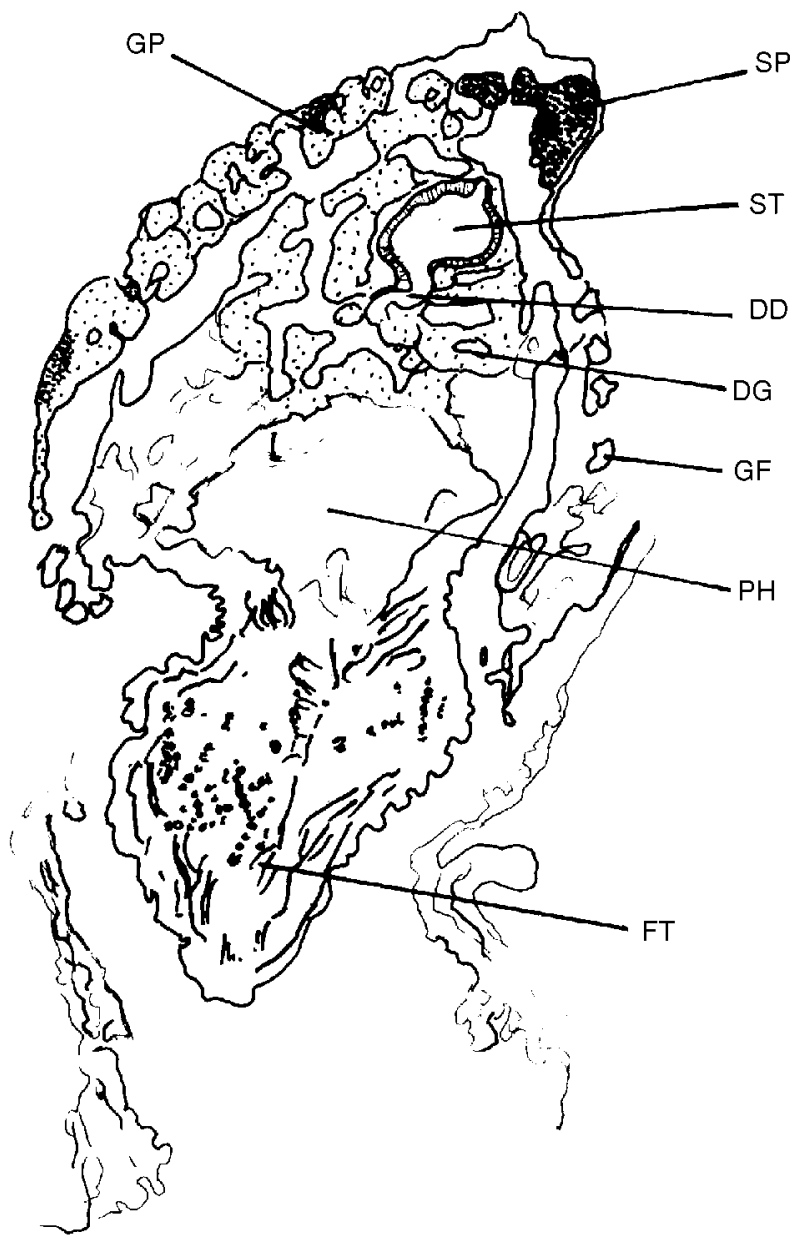

Figure 15. Transverse section though the stomach of a specimen from Atlantis II, station 115, North America Basin. Scale bar: $0.25 \mathrm{~mm}$. DD, digestive duct; DG, digestive gland; FT, foot; GF, gill filament; GP, gonadial pouch; PH, pedal haemocoele; SP, sperm; ST, stomach.

junction to the body wall. The lamellae of the outer demibranch are small and reflected postero-dorsally. The descending lamella of the outer demibranch is narrow and is attached to approximately the posterior two-thirds of the gill axis. The ascending lamella is half the size of the descending lamella and confined to a small area anterior to the posterior adductor. Except for a small number of undifferentiated cells at the antero-ventral margin of the posterior adductor forming a gill rudiment, the outer demibranch is not present in shells $<2.0 \mathrm{~mm}$ total length (Figure 9). Posterior to the foot, the left and right gill axes are attached to each other by a tissue bridge that then attaches to the mantle at the point of ventral fusion forming the exhalent siphon (Figure 10). In cross section the filaments are unmodified. They do not show any gland cells on the abfrontal surface to which spermatozoa may attach such as is described by Morton (1980) and O'Foighil (1985).

There are no palps. The mouth opens ventral to the anterior adductor, at the tip of a very muscular and extended oesophagus. In some specimens the tissue surrounding the mouth forms a thickened rim (Figures 11 \& 12). Posteriorly the oesophagus is deeply ridged with a

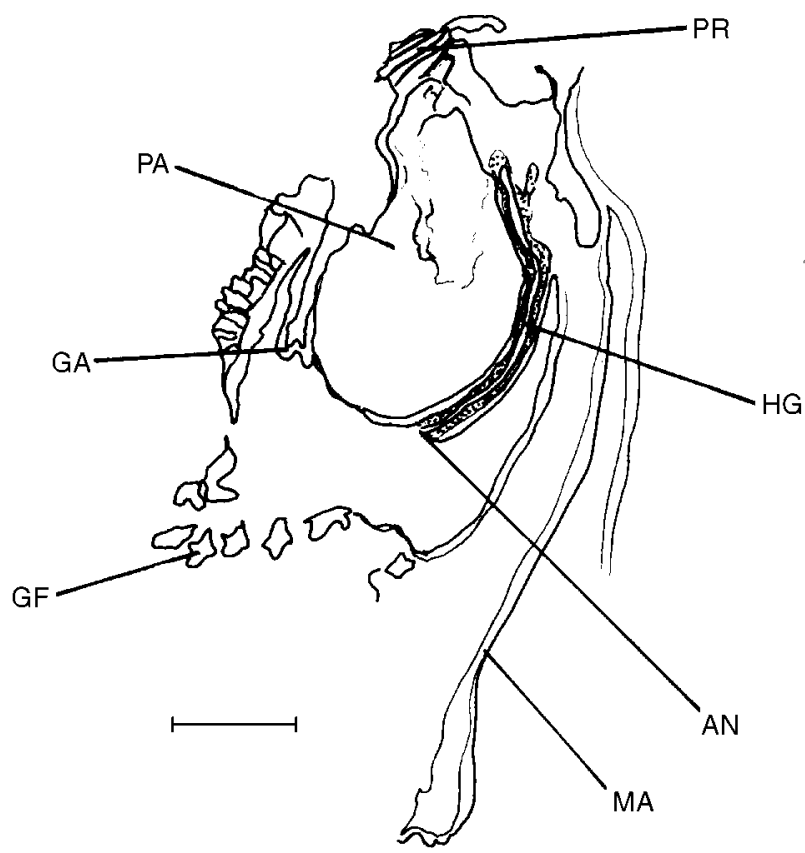

Figure 16. Transverse section through the posterior adductor muscle and hind gut of a specimen from Atlantis II, station 115, North America Basin. Scale bar: $0.1 \mathrm{~mm}$. AN, anus; GA, gill axis; GF, gill filament; HG, hindgut; MA, mantle; PA, posterior adductor muscle; PR, posterior pedal retractor muscle.

wide lumen possibly used for initial storage (Figure 13). The oesophagus forms something analogous to a suctorial buccal mass. Fine muscle fibres extend from the shell ventral to the anterior adductor to a point immediately dorsal to the mouth (Figure 12). These would appear to be protractor muscles that probably direct the positioning of the mouth. No new structures make up the oesophageal walls. The buccal mass is made up of much-elongated columnar epithelial cells surrounded by a thick layer of longitudinal muscle cells covered by a typical external epithelium (Figures 13 \& 14). Posteriorly the oesophagus opens into a small stomach. Ducts from the floor and from the right side of the stomach lead to extensive digestive diverticula that lie anterior and lateral to the stomach (Figure 15). The midgut and style sac are combined. Sections show that there is a style. The hind gut, which is very slender with an extremely narrow lumen, takes a simple course dorsally from the limit of the style sac, passing through the heart and over the posterior adductor muscle to the anus (Figures $9 \& 16$ ).

The kidney is relatively large lying dorsal and parallel to the margin of the outer demibranch (Figures $8 \& 9$ ).

The gonads are comprised of a gill-like visceral extension on each side external to the main body wall (Figures $8 \& 12$ ). Sections suggest that this species may be a consecutive hermaphrodite. Within the gonadial pouches radiating channels pass spermatocytes or oocytes to a gonadial duct on each side. Sectioned material shows that spermatozoa are stored posteriorly on each side in an enlarged part of the duct posterior to the stomach and close to the dorsal margin anterior to the ligament before being released via a short vas deferens into the suprabranchial cavity (Figures $8 \& 15$ ). The condition of the mature female is unknown. Primary oocytes are present in a 
sectioned specimen with mature sperm. One specimen was obtained with many larvae (about 800 in a specimen $2.5 \mathrm{~mm}$ total length) packed within the mantle cavity adhering to the outside of the gills and between gonadial pouch and visceral wall. These larvae, measuring approximately $140 \mu \mathrm{m}$ in length, were at the late veliger stage. From the large size of the prodissoconch $(307-345 \mu \mathrm{m})$ it was expected that a small number of large yolky eggs might have been produced to develop directly to the juvenile stage within the mantle cavity or suprabranchial chamber, but no veliconch larvae were found within the mantle cavity. It is assumed that the late veligers are released to seek a host species and while they remain in the plankton they feed and grow, the variation in prodissoconch size relating to the length of time taken to find the host.

The nervous system is typical of that found in other bivalves, consisting of cerebral, visceral and pedal ganglia. The ganglia and the commissures are relatively well-developed. The cerebral ganglia form a bulge on the buccal mass dorsal and immediately posterior to the mouth (Figure 12).

\section{DISGUSSION}

Even by montacutid standards this is a most remarkable bivalve. First, the mouth and oesophagus have become suctorial, with hypertrophied musculature, and this has been accompanied by the complete loss of the palps. Second, the gonad is largely contained in two anterior, flattened, leaf-like extensions of the body that occupy the space where the anterior portion of a gill would be expected to occur. As a result of this, the gill, which is restricted largely to the inner demibranch, occurs posterior to the gonad.

Genital lobules have been described by Oldfield (1961) in Montacuta ferruginosa and M. substriata and by Ockelmann (1965) in Montacuta tenella Lovén, but none to the degree of complexity seen in Mysella verrilli. In the latter, the form is leaf-like and on casual observation is not immediately distinguished from gills. Only in the Thyasiridae are comparable paired pouches of the body present (Payne \& Allen, 1991), however, those in the Thyasiridae are extensions from the centre of the lateral body wall with the gills overlying the pouches. In $M$. verrilli the pouches extend from the dorsal margin of the visceral mass and have the gill attached, and thus differing significantly from those of the Thyasiridae.

The gills of deep-sea bivalves are frequently reduced in size (e.g. Oliver \& Allen, 1980), a modification that is possibly related to changed respiratory demand under high pressure or possibly to a reduced filtration requirement. As a result, mantle space is available for body extension.

All mysellids reported upon to date are associated with an invertebrate host (Morton \& Scott, 1989). Thus, it is reasonable to assume that $M$. verrilli is also associated with a benthic invertebrate. In view of the extremely narrow diameter of the hind gut and the lack of contents, together with the simple nature of the suctorial mouth, it is likely that $M$. verrilli is an ectoparasite restricted to a fluid or gelatinous diet. It probably parasitizes one of the more common deep-sea coelen- terates such as Cerianthus multiplicatus Carlgren (Rice et al., 1982). Other montacutids are known to occur on cerianthids (Ponder, 1971; Morton, 1980). Whether $M$. verrilli feeds on the tissues of the host or on the food of the host is not known. Also, whether the much reduced gill passes filtered particles to the mouth to be ingested by suction or, simply rejected as pseudofaeces, is not known. The digestive diverticula are well-formed with extensive digestive tubules. This, together with the presence of a style, leads to the deduction that $M$. verrilli digests its food in the same manner as other bivalves. Nevertheless, all specimens examined have an extremely narrow hindgut, with a narrow lumen and without content and it must be assumed that whatever is ingested contains little solid waste.

Associated with commensal and parasitic life is reproductive specialization and in this the Galeommatoidea are no exception. Specialization may include hermaphroditism, sperm storage and sexual dimorphism (Gage, 1968; O'Foighil, 1985, 1987; Jenner \& McCrary, 1968; Morton, 1976, 1980). Brooding of the young within the mantle cavity is also a feature of members of the superfamily (O'Foighil, 1985). Mysella verrilli is also no exception. It is an hermaphrodite, it stores its sperm and broods its young. Sperm are stored in the posterior part of the gonadial ducts and not in an accessory organ formed by the gill axis posterior to the foot as in Mysella bidentata (Montagu) (Deroux, 1961; Ockelmann \& Muus, 1978) and Montacutona compacta (Gould) (Morton, 1980). Spermatophores of the type described by Ockelmann \& Muus (1978) in M. bidentata were not seen nor is there evidence of sperm attachment to the abfrontal surface of the inner demibranch as described in Mysella tumida (Carpenter) (O'Foighil, 1985). Unlike most other montacutids, the developing eggs are not contained within the suprabranchial chamber, but anteriorly within the mantle cavity. The only other species recorded to date to do this is Montacuta percompressa Dall (Chanley \& Chanley, 1970). It might be assumed that when the eggs are laid within the mantle cavity they are directed anteriorly to the glandular region close to the point where the inhalant flow carrying sperm will enter the mantle cavity.

While it might be thought that the unusual morphology of M. verrilli warrants generic rank, it is clear that in shell structure it differs little from other species of Mysella, all of which are commensal or ectoparasitic with other invertebrates and which might be expected to exhibit morphological specialization. Because of this, $M$. verrilli is retained within the genus.

I wish to thank Dr J.D. Taylor and Mrs Joan Pickering of the Natural History Museum, London (BMNH), Mr P. Greenhall of the Smithsonian Museum, National Museum of Natural History, Washington DC (USNM) and Mr E.A. Lazo-Wasem of the Peabody Museum of Natural History, Yale University (YPM), for their kind assistance.

\section{REFERENCES}

Abbott, R.T., 1974. American seashells. New York: Van Nostrand. Boss, K.J., 1965. Symbiotic erycinacean bivalves. Malacologia, 3, 183-195. 
Chanley, P. \& Chanley, M., 1970. Larval development of the commensal clam, Montacuta percompressa Dall. Proceedings of the Malacological Society of London, 39, 59-67.

Dall, W.H., 1899. Synopsis of the recent and tertiary Leptonacea of North America and the West Indies. Proceedings of the United States National Museum, XXI, 873-879.

Deroux, G., 1960. Formation régulière de mâles mûrs, de taille et d'organisation larvaire chez un Eulamellibranche commensal (Montacuta phascolionis Dautz). Comptes Rendus Hebdomadaire des Séances de l'Académie des Sciences. Paris, 250, 2264-2266.

Deroux, G., 1961. Rapports taxonomiques d'un Leptonacé non décrit 'Lepton subtrigonum' Jeffreys (nomen nudum-1873). Cahiers de Biologie Marine, II, 99-163.

Gage, J., 1968. The mode of life of Mysella cuneata, a bivalve 'commensal' with Phascolion strombi (Sipunculoidea). Canadian Fournal of Zoology, 46, 919-934.

Jeffreys, J.G., 1866. Report of dredging among the Hebrides. Description of a new species of Montacuta. Montacuta tumidula, Jeffreys. Annals and Magazine of Natural History, series 3, 18, 396-397.

Jeffreys, J.G., 1867. Report on dredging among the Hebrides. Report of the British Association for the Advancement of Science, 1866, 186-193.

Jeffreys, J.G., 1869. British conchology. London: V.J. van Voorst.

Jenner, C.E. \& McGrary, A.B., 1968. Sexual dimorphism in erycinacean bivalves. American Malacological Union, Annual Report, 35, 43.

Marshall, J.T., 1897. Additions to 'British Conchology' Fournal of Conchology, 8, 338-372.

Morton, B., 1976. Secondary brooding of temporary dwarf males in Ephippodonta (Ephippodontina) oedipus sp. n. (Bivalvia: Leptonacea). Fournal of Conchology, 28, 365-369.

Morton, B., 1980. Some aspects of the biology and functional morphology (including the presence of a ligamental lithodesma) of Montacutona compacta and M. olivacea (Bivalvia: Leptonacea) associated with coelenterates in Hong Kong. Fournal of Zoology, 192, 431-455.

Morton, B. \& Scott, P.H., 1989. The Hong Kong Galeommatacea (Mollusca: Bivalvia) and their hosts, with descriptions of new species. Asian Marine Biology, 6, 129-160.

Ockelmann, K.W., 1965. Redescription, distribution, biology, and dimorphous sperm of Montacuta tenella Lovén (Mollusca, Leptonacea). Ophelia, 2, 211-221.

Ockelmann, K.W. \& Muus, K., 1978. The biology, ecology and behaviour of the bivalve, Mysella bidentata (Montagu). Ophelia, 17, 1-93.
O'Foighil, D., 1985. Sperm transfer in the brooding bivalve Mysella tumida. Biological Bulletin. Marine Biological Laboratory, Woods Hole, 169, 602-614.

O'Foighil, D., 1987. Gytotological evidence for self-fertilization in Lasaea subviridis (Galeommatacea: Bivalvia). International Fournal of Invertebrate Reproduction and Development, 12, 83-90.

Oldfield, E., 1961. The functional morphology of Kellia suborbicularis (Montagu), Montacuta ferruginosa (Montagu) and M. substriata (Montagu), (Mollusca Lamellibranchiata). Proceedings of the Malacological Society of London, 34, 255-295.

Oliver, G. \& Allen, J.A., 1980. The functional and adaptive morphology of the deep-sea species of the family Limopsidae (Bivalvia: Arcoida) from the Atlantic. Philosophical Transactions of the Royal Society, 291, 77-125.

Payne, C.M. \& Allen, J.A., 1991. The morphology of deep-sea Thyasiridae (Mollusca: Bivalvia) from the Atlantic Ocean. Philosophical Transactions of the Royal Society B, 334, 481-566.

Ponder, W.F., 1971. Montacutona ceriantha n. sp., a commensal leptonid bivalve living with Cerianthus. Fournal de Conchyliologie, 109, 15-25.

Popham, L.M., 1940. The mantle cavity of some of the Erycinidae, Montecutidae and Galeommatidae with special reference to the ciliary mechanisms. Fournal of the Marine Biological Association of the United Kingdom, 24, 549-587.

Rice, A.L., Aldred, R.G., Darlington, E. \& Wild, R.A., 1982. The quantitative estimation of the deep-sea megabenthos; a new approach to an old problem. Oceanologica Acta, 5, 63-72.

Salas, C. \& Gofas, G., 1998. Description of four new species of Neolepton Monterosato, 1875 (Mollusca: Bivalvia: Neoleptonidae), with comments on the genus and on its affinity with the Veneracea. Ophelia, 48, 35-70.

Verrill, A.E., 1884. Second catalogue of Mollusca recently added to the fauna of the New England coast and adjacent parts of the Atlantic, consisting mostly of deep-sea species with notes on others previously recorded. Transactions of the Connecticut Academy of Arts and Sciences, VI, 139-294.

Verrill, A.E., 1885. Results of the explorations made by the steamer 'Albatross' off the northern coast of the United States in 1883. Report of the United States Commissioner for Fish and Fisheries for 1883, Appendix D, Natural History and Biological Research, 503-601.

Verrill, A.E. \& Bush, K.J., 1898. Revision of the deep-water Mollusca of the Atlantic coast of North America, with descriptions of new genera and species. Proceedings of the United States National Museum, XX, 775-901.

Submitted 2 March 2000. Accepted 13 June 2000. 